\title{
ДО ПИТАННЯ ПРО НАДГРОБКИ ВІЗАНТІЙСЬКОГО ХЕРСОНУ В КОНТЕКСТІ ТРАНСФОРМАЦЇ̈ СВІТОГЛЯДУ МІСТЯН
}

\author{
Н. О. Пімуліна
}

\begin{abstract}
Пішуліна Н. О. До питання про надгробки візантійського Херсону в контексті трансформації світогляду містян. Херсонес-Херсон $є$ унікальною пам'яткою, оскільки містить археологічний матеріал двох епох: античної та візантійської. На його прикладі можна прослідкувати трансформаційні процеси релігійного світогляду. Надгробки є своєрідною візуальною репрезентацією культу. У статті зосереджено увагу на типологічній класифікації цієї групи пам'яток, їх функціональних особливостях на тлі трансформації міста з античного на середньовічне, на тегах, найбільш розповсюджених у текстах епітафій; внесено деякі корективи щодо вивчення херсонських надгробків різними дослідниками.
\end{abstract}

Ключові слова: Херсонес; поховання; надгробки; епітафії; типологія.

Пищулина Н. О. К вопросу о надгробиях византийского Херсона в контексте трансформации мировоззрения горожан. На поприще археологии Херсонеса трудится не одно поколение ученых. Благодаря их изысканиям Херсонес-Херсон предстает как уникальный памятник, с одной стороны, античного, с другой - византийского периодов. На его примере можно проследить трансформационные процессы религиозного мировоззрения. Надгробия - своеобразная репрезентация культа. Акцентируется внимание на типологической классификации этой группы памятников, их функциональных особенностях, на тегах, наиболее распространенных в текстах эпитафий; уточняются некоторые данные, изложенные исследователями ранее.

Ключевые слова: Херсонес; захоронение; надгробия; эпитафии; типология.

Pishchulina N. On the Issue of the Byzantine Cherson Gravestones in the Context of the Transformation of the Townspeople Worldview. Chersonesos-Cherson is a unique monument since it contains archaeological material of two epochs: ancient and Byzantine. By its example one can trace the transformational processes of the religious worldview. The gravestones are a peculiar visual representation of the cult. We will focus attention on the typological classification of this group of monuments, their functional features against the background of the transformation of the city from the ancient to the medieval one, on the tags most commonly used in epitaph texts, make some adjustments to study of Cherson gravestones by different researchers.

Keywords: Chersonesus; burial; tombstones; epitaphs; typology.

Херсонес-Херсон є унікальною пам'яткою античної та візантійської епох. Некрополь античного Херсонеса містить велику кількість матеріалу для дослідження, зокрема епітафій. Але до візантійського періоду, за нашими підрахунками, сьогодні можна віднести лише 31 надгробок та ще два золотоординського й османського часу ${ }^{1}$.

С. Б. Сорочан у монографічній роботі про візантійський Херсон зазначав, що приблизно від 15 до 23 мешканців міста могли бути зайняті у поховальній справі ${ }^{2}$. Однак писемні херсонеські джерела, у яких йдеться про поховальний обряд, практично відсутні. Саме тому особливу увагу варто приділити археологічним матеріалам, оскільки надгробки можна аналізувати і як матеріальні пам’ятки, і як письмові - епіграфічні джерела.

Вивченням херсонських епітафій займалися декілька дослідників. Видання та аналіз усіх виявлених надгробків - носіїв грецьких написів - здійснив ще академік В. В. Латишев. Його цікавила, перш за все, епіграфічна складова ${ }^{3}$. Низку статей А. Ю. Виноградова також присвячено дослідженню текстів на надгробках. Фактично лише він наводив аргументацію щодо датування написів та пояснював запропонований переклад

Найбільш повний каталог сьогодні містить Інтернет-ресурс IOSPE - частина міжнародного проекту 3 давньогрецьких та латинських написів Північнопонтійського регіону. Саме А. Ю. Виноградов є автором вступу, перекладів та коментарів текстів візантійського блоку ${ }^{5}$. Ще одна спроба каталогізувати матеріал належить М. В. Фоміну: спочатку у ди- 
сертаційній роботі, потім - в виданій монографії ${ }^{6}$ Однак каталоги А. Ю. Виноградова та М. В. Фоміна співпадають далеко на завжди. У зовсім іншому контексті, з огляду на уявлення херсонеситів про смерть, деякі надгробки було розглянуто С. Б. Сорочаном. Епітафiї автор наводив як певні аргументи до поховального обряду․

Щодо типології, то наша спроба є першою. С. Б. Сорочан і А. Ю. Виноградов торкалися цього питання, але подальшого розгляду воно не набуло. У роботах дослідників як принцип поділу прослідковується категорія «форма». Зокрема, С. Б. Сорочан зазначав, що у VI-IX ст. херсонесити, та й загалом ромеї, використовували стовпоподібні та стелоподібні надгробки з промальованими зображеннями хреста, а також хрестоподібні надгробки ${ }^{8}$. Щодо форми пам'яток, то, додамо, окрім хрестоподібних епітафій та епітафій із зображеннями хреста, кладовище Херсону містить надмогильні камені лише 3 текстом, без будь-яких зображень.

А. Ю. Виноградов в каталозі IOSPE у категорії «різновид» відокремлював стелу, плиту та хрест. Однак логічного ряду стосовно форми не прослідковується. Наприклад, об'єкт V 88 позначений як стела, V 78 фігурує як плита, V 86 - як хрест. У всіх випадках форма надгробків досить схожа; вони можуть бути віднесені до яйцеподібних. Через це зробимо припущення, що у автора терміни «стела» та «плита» виступають як синоніми. Загалом, стела (грец. «пам'ятник, меморіал») $)^{9}$ - характерний термін для позначення античних пам'яток; це вертикальний пам'ятник, що розташовувався безпосередньо над поховальною спорудою. Плита, у археологічному контексті, - горизонтальне перекриття склепу чи могили. Наприклад, могила № 110 мала кам’яні плити-перекриття (1996 р., А. В. Магда), а № 6 - плити-перекриття з сарматського вапняку; щілини були закладені дрібним камінням (1939 р., С. Ф. Стржелецький $)^{10}$. На жаль, через відсутність інформації відносно археологічного контексту знахідок, у більшості випадків дуже складно прослідкувати горизонтальне чи вертикальне положення ймовірних надгробків, від чого могли залежати їхні функціональні характеристики. Іноді невідоме й місце зберігання пам'ятника. На сьогодні усі надгробки візантійського Херсона містять написи, на відміну від плит-перекриттів. Хоча у другому випадку матеріал міг бути використаний не вперше.

Таким чином, оскільки стела - більш вузьке поняття, щоб відокремити античні епітафії від візантійських, щодо останніх будемо використовувати загальний термін «надмогильна плита», на відміну від «плити-перекриття». А. В. Буйських, аналізуючи численні античні надгробки, також зазначала, що для типологізації епітафій необхідно базуватися на загальноприйнятому для подібних класифікацій методичному принципі - формоутворюючому ${ }^{11}$.

Складаючи типологію, ми зупинилися на двох позиціях: 1) форма, матеріал та нанесені зображення; 2) лапідарні епітафії та епітафії в контексті поховального настінного живопису (рис. 1). Останній принцип закладений у походженні терміну. Epitaphius в перекладі з латини - надмогильний камінь (або промова, в іншому значенні) ${ }^{12}$. В грецькій мові єлıт́́ $\varepsilon \pi$ вказує на місцезнаходження, тобто, по суті, «будь-що над похованням». Відповідно до перекладу з грецької мови написи на стінах склепів також можна інтерпретувати як надгробки.

На сьогодні в Херсонесі відкрито 13 склепів з ранньохристиянськими розписами. Ці пам'ятники неодноразово були предметом спеціальних досліджень. Три 3 них - епітафiï ${ }^{15}$. Матеріал, на який нанесено поховальні написи, - стіна склепа, штукатурка. Хронологічно вони охоплюють період IV-V ст., тобто зазначений тип пам'ятки є одним із найбільш ранніх на херсонському кладовищі. На відміну від лапідарних епітафій, де виникають питання стосовно інтерпретації, ці написи знаходяться безпосередньо у склепах, тобто мали відношення до похованих у них. До того ж, самі тексти -поховального характеру.

Лапідарні епітафії, що переважають, за формою ми умовно поділили на хрестоподібні та плити. Надгробки у вигляді хрестів традиційно вважаються особливістю Константинополя та його околиць ${ }^{16}$. В. М. Зубар і А. І. Хворостяний зазначали: хрест став атрибутом херсонських й, загалом, кримських християнських надгробків не раніше V-VII ст. ${ }^{17}$. Проте сьогодні відкриті херсонські епітафії IV-V ст. Це три зазначені вище надгробки у поховальних камерах та ще дев’ять лапідарних, чотири з яких у формі хрестів. 


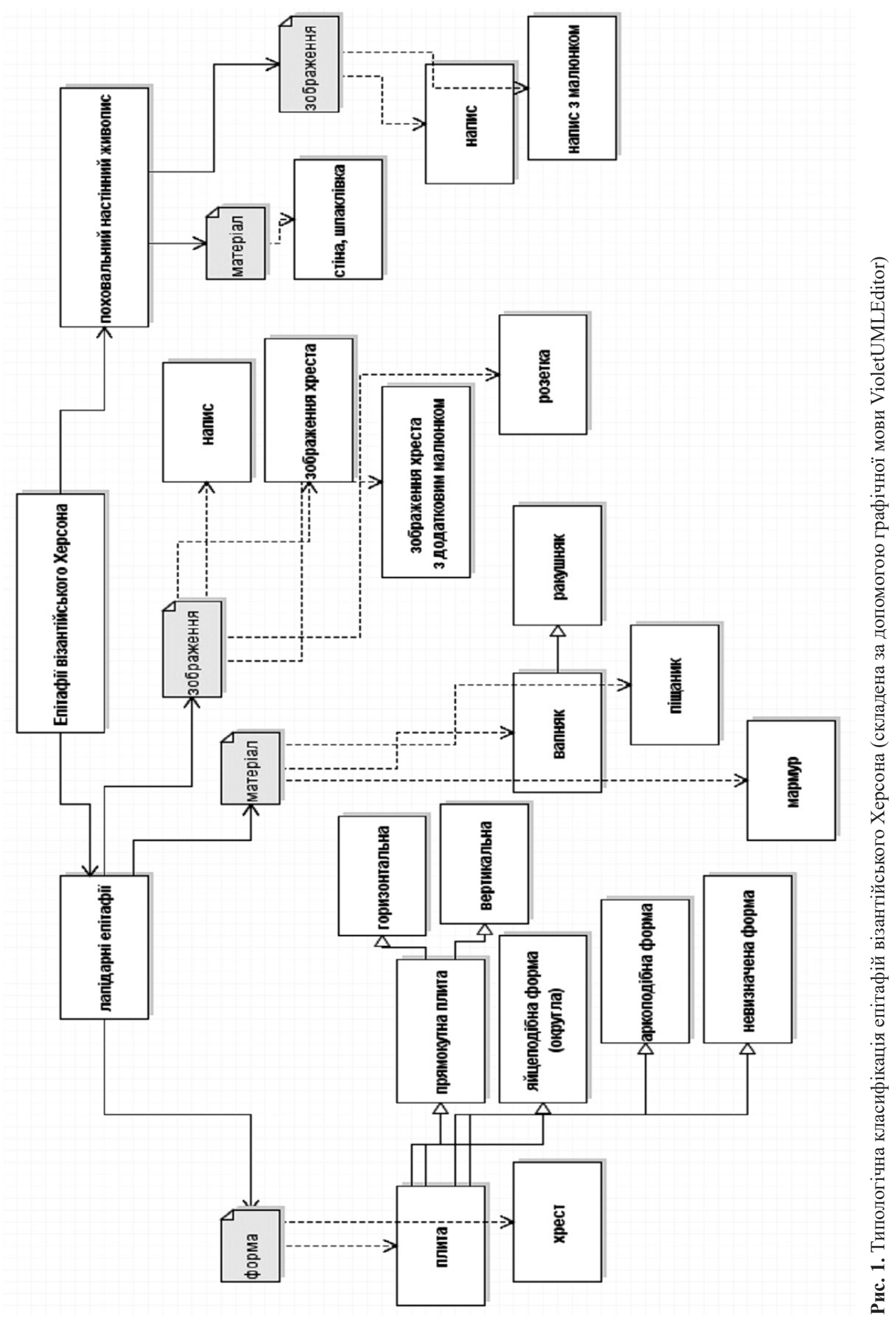


Найбільш рання херсонська епітафія у вигляді хреста датується IV ст. На ній зупинимося детальніше. У каталозі М. В. Фоміна наведено два різних пам'ятника під одним порядковим номером. Автор зазначив інв. № 4144, що не відповідає напису «Памятник святой мученицы Анастасии». А. Ю. Виноградов, аналізуючи епіграфічні джерела IV ст., навпаки, позначив саме цей пам'ятник під інв. № 4140. Звідси й плутанина 3 археологічним контекстом знахідок. С. Б. Сорочан навів обидва об’єкта: № 4144 з зображенням епітафії на одній сторінці, а № 4140 - в примітках на іншій. У каталозі IOSPE присутні два пам’ятника під різними номерами: V 76 та V $62^{18 .}$

Аналізуючи цю групу надгробків зазначимо, що хронологічні межі їх спорудження IV-V ст. Це ранньовізантійські пам'ятники, чотири з яких були знайдені в безпосередній близькості від склепів; археологічний контекст однієї епітафії не відомий. Чотири з них були виготовлені з м'якого вапняку, один надгробок - 3 м'якого піщаника. Загалом, візантійські херсонеські надгробки в переважній більшості були виготовлені з вапнякових плит (24 331 ).

Категорія «плита» (21 об’єкт) - узагальнююча назва для декількох форм. Найбільш розповсюджені - плити прямокутні вертикальні чи горизонтальні. Різниця між ними лише в розмірі (більша висота чи ширина). Хронологічно такі пам'ятники охоплюють IV$\mathrm{XIV}$ ст., вони зустрічалися протягом всього християнського періоду міста. 14 з них були виготовлені з вапняку, один надгробок - з мармуру. Останній, як і можна було очікувати, використовувався повторно.

Слід звернути увагу на надгробок під інв. №101/36504 ${ }^{19}$. Певно, на об'єкт були нанесені декілька епітафій різного часу. Тому в каталозі М. В. Фомін позначив пам'ятник двічі: сторону Б з інвентарним номером, сторону А - без. У каталозі IOSPE наведено зображен-

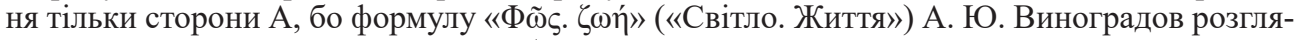
дав як демонстративну. Сторона А була зазначена як окремий намогильний пам'ятник у спільній роботі С. Б. Сорочана та В. М. Зубаря. На архівній картці міститься фото сторони Б, сторона ж А промальована олівцем в лівому куті.

Щодо демонстративного характеру формули, зауважимо, що подібний напис зустрічається на херсонських епітафіях двічі: «1: [Господ]и, упокой [ду]ши, здесь лежащие, аминь: [Д]амиана, Маргариты и детей их 2: Свет. Жизнь»; «1: Свет, жизнь 2: Памятник Петра моряка. Памятник Христофора и Сисинія» (переклад А. Ю. Виноградова). С. Б. Сорочан звернув увагу, що на ранньовізантійських надгробках і на стінах в поховальних камерах такий напис зустрічається неодноразово ${ }^{20}$. А. Ю. Виноградов трактував напис наступним чином: «Я - світло, я - життя». Як припущення, звернемося до писемного джерела. Феодорит Кірський пригадував в «Церковній історії» (V ст.), що коли померлого святителя Іоанна Хрисостома переносили до Константинополя, то багато людей тримали у руках свічки - Боспор здавався охопленим полум'ям ${ }^{21}$.

Щодо сторони Б, А. Ю. Виноградов припустив: «памятник Петра моряка» та «памятник Христофора и Сисинія» - написи різного часу. Тож цілком можливо, що ми маємо справу з надмогильною плитою, яку використовували у поховальній практиці тричі.

До категорії «зображення» відносно лапідарних епітафій ми умовно віднесли наступні позиції: напис, хрест, хрест з малюнком та розетка. Написи присутні на всіх херсонських надгробках, що в багатьох випадках спрощує датування носія. Хрест, як нанесене зображення, міститься на п'яти пам'ятниках. I надгробки у формі хреста, і хрести, вписані в надгробки, мали однакове змістовне навантаження. На одній з таких епітафій прослідковується зображення двох дерев.

Розетка була промальована на трьох пам'ятниках. В. М. Зубар та А. І. Хворостяний писали, що на ранніх християнських надгробках Херсонеса та Південно-Західної Таврики не було хрестів, а лише чотирьохпелюсткові розетки, вписані в коло 22 . За авторами, фактично дослівно, такий самий висновок зробила Н. М. Ликова ${ }^{23}$. Однак сьогодні дослідники датують розетки IV-XIV ст. - вони зустрічалися впродовж усього офіційно християнського періоду міста.

Про використання розеток у християнській поховальній практиці вказано в нещодавно виданій монографії Ю. Матвєєвої. Розглядаючи семантику декоративних тканин в мозаїках Равенни, авторка неодноразово акцентувала увагу на надгробках, у тому числі Херсонеса-Херсона. За Ю. Матвєєвою, зображення в розетках могли бути символами трапези безсмертя ${ }^{24}$. 
Поховальні написи - найбільш розповсюджений тип написів на теренах Північного Причорномор'я і не тільки. Вже М. І. Новосадський (1914р.) стосовно грецьких християнських написів, а потім М. М. Болгов відповідно до текстів на пам'ятках V ст. у Керчі, запропонували таку типологію: 1) ім'я; 2) розповідь про померлого; 3) автобіографія ${ }^{25}$. На херсонських надгробках відображені лише перша та третя позиції: вказано ім'я, інколи родинні зв'язки.

Усі формули, що містяться на херсонських епітафіях, проаналізував А. Ю. Виноградов, навівши аналогії ${ }^{26}$. Тому ми зосередили увагу не на формулах, а на тегах. Аналіз було здійснено за допомогою комп'ютерної програми MAXQDA10. Як видно 3 аналізу тегів, першу позицію займають поняття «божий», «раб», «спочив», «тут». Другу позицію - «во», «пам'яті», «упокой» (рис. 2). Хмара тегів будує досить зрозумілий логічний ряд. Відокремимо наступні акценти: «тут», «спочив», «упокой», «во», «пам'яті», «раб», «божий», що, на наш погляд, слід розуміти наступним чином: на цьому місці поховання (утилітарна функція, локалізація поховання); надгробок - знак пам'яті (категорія memoria) ${ }^{27}$; та релігійний маркер (на цьому місці поховання християнина). Візантійські написи, як і язичницькі, несли відбиток життя того суспільства.

3 точки зору функціонального навантаження, слід відокремити дві категоріï: memoria, здатність втримати знання про минуле, та утилітарне значення. Перший надгробок, за Біблією, маццева, зведено на могилі Рахілі ${ }^{28}$; в епоху Першого храму знайдені людські кістки необхідно було відзначати циюном (знаком) для їх подальшого поховання ${ }^{29}$.

Підбиваючи підсумки, згадаємо висловлю-

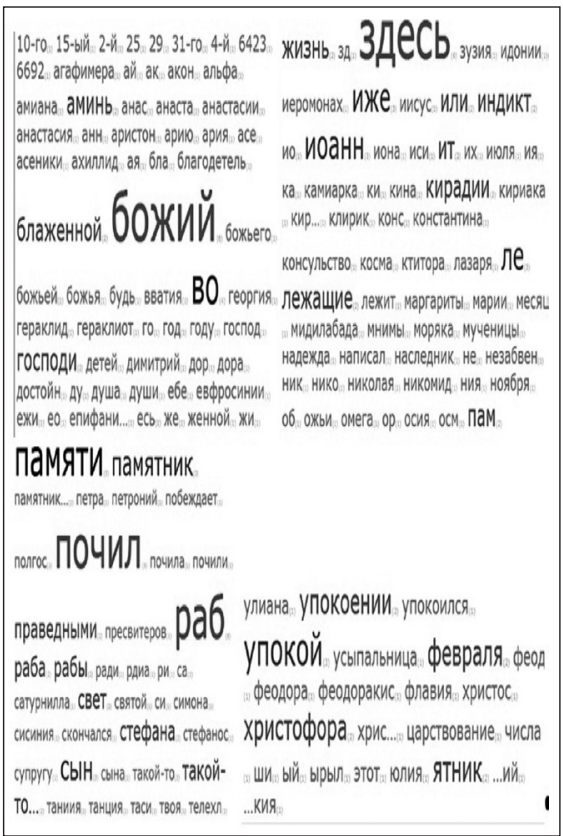

Рис. 2. Хмара тегів написів на епітафіях візантійського Херсону (складена за допомогою програми MAXQDA10).

вання Ф. Арьєса: «...нема надгробків без небіжчиків, нема небіжчиків без надгробків» ${ }^{30}$. У візантійській поховальній традиції прослідковується протиріччя другій частині твердження, що цілком пояснюється особливостями релігійного світогляду ${ }^{31}$. «Могила стає безіменною», - підкреслив автор, акцентуючи увагу як на не досить частому використанні епітафій, так і на лаконічності, на відміну від античного періоду, написів на них. Тут, безумовно, слід зазначити, що надгробки використовувалися протягом усього візантійського періоду, без хронологічних прогалин. Надалі їхню функцію mеmoria почали виконувати поминальні списки.

Херсонес познайомився 3 християнством вже у I ст., але на кладовищі відсутні пам'ятники, які можна віднести до християнських надгробків раніше IV ст. Матеріали пізньоантичного - ранньовізантійського періоду інтерпретувати достатньо складно. В процесі трансформації, що прослідковується за матеріалами Херсонесу, нове не витіснило старе, а надало звичним, традиційним речам новий сенс. Упродовж століть символічне навантаження вкладалося в образи багатьох поховальних елементів та підпорядковувалося змінами в масовому світогляді. Однак форми вираження досить часто залишалися старими, добре відомими.

Відповідно до утвердження християнства на державному рівні, невеликій групі населення - носіям нової віри - навряд чи хотілось звертати на себе увагу. Тому і надгробки на християнських могилах не обов'язково були позначені відбитком нової релігії. До того ж у колі навіть однієї сім’ї могли бути різні світоглядні уявлення, що можна прослідкувати за матеріалами античного Херсонеса (наприклад, використання в рамках однієї родини як інгумації, так і кремації). 
Починаючи з IV ст., за характером поховальних написів можна вивести чітку формулу: «тут поховання християнина». Написи присутні на всіх відкритих херсонеських епітафіях. До того ж 16\% складають промовисті хрестоподібні надгробки і 16\% - намогильні плити із зображеними хрестами. Епітафії були своєрідною візуальною репрезентацією культу.

Ті дані, що отримано за результатами аналізу херсонеських надгробків, не $\epsilon$ достатніми для обгрунтованих статистичних висновків. 3 них можна отримати лише загальне уявлення щодо поховальної традиції та обряду населення візантійського провінційного міста. Запропонована типологія, безумовно з корективами, допоможе вийти на вирішення нових завдань, розглянути епітафії як поховальний елемент для більш цілісної картини про візантійські релігійні уявлення.

${ }^{1}$ См.: Волков И. В. Два надгробных камня из Музея заповедника «Херсонес Таврический» // Тhe Genoese Gazaria and the Golden Horde. Кишинев, 2015. С. 573-577.

${ }^{2}$ Сорочан С. Б. Византийский Херсон (вторая половина VI - первая половина X вв.). Очерки истории и культуры. Т. 1-2. Харьков, 2005. С. 1032.

${ }^{3}$ Древности южной России. Греческие и латинские надписи, найденные в южной России в 1895 1898 годах с объяснениями акад. В. В. Латышева // Материалы по археологии России (далее - МАР). СПб., 1899. № 23. С. 49-50; Латышев В. В. Надписи, найденные в Херсонесе Таврическом в 1889-91 года // МАР. СПб., 1891. Вып. 9. С. 36-37, № 29, 30; Латышев В. В. Греческие и латинские надписи, найденные в Южной России в 1892-1894 года // МАР. СПб., 1894. Вып. 17. С. 80; Латышев В. В. Сборник греческих надписей христианских времен из Южной России. СПб., 1896. С. 23-26, № 12, С. 26-27, № 13, С. 31-32, № 24, С. 33-34, № 27, С. 35, № 29; Латышеев В. В. Греческие и латинские надписи, найденные в Южной России в 1895-1898 гг. // МАР. СПб., 1899. Вып. 23. С. 46-49, № 45; Латышев В. В. Эпиграфические новости из Южной России // Известия Археологической комиссии (далее - ИАК)). СПб., 1906. Вып. 18. С. 123-124, № 38; Латышев В. В. Эпиграфические новости из Южной России // ИАК. СПб., 1906а. Вып. 18. С. 123-124, № 38, С. 124-125, № 39; Латышеев В. В. Эпиграфические новости из Южной России // ИАК. СПб., 1908. Вып. 27. С. 28-29, № 22, С. 29-30, № 23, C. 30-33, № 24-26, 28.

${ }^{4}$ Vinogradov A. Von der antiken zur christlichen Koine: typische und untypische Inschriften des nördlichen Schwarzmeerraums // Unekoiné pontique. Par Bresson A., Ivanchik A., Ferrary J.-L.Bordeaux. 2007. S. 263; Виноградов А. Ю. Загородный крестообразный храм в Херсонесе и его надписи // Вопросы эпиграфики. 2009. Вып. 3. С. 227-229, 241, 243, 245, 247; Виноградов А. Ю. «Миновала уже зима языческогобезумия...». Церковь и церкви Херсона в IV веке по данным литературных источников и эпиграфики. М., 2010. С. 89-152.

${ }^{5}$ Inscriptiones antiquae Orae Septentrionalis Ponti Euxini graecae et latinae. URL: http://iospe.kcl. ac.uk/index-ru.html (дата обращения: 10.08.17).

${ }^{6}$ Фомин М. В. Погребальная традиция и обряд в византийском Херсоне (IV-X вв.). Харьков, 2011. C. $265-272$.

${ }^{7}$ Сорочан С. Б. Византийский Херсон ... С. 1031-1087; Зубарь В. М., Сорочан С. Б. У истоков христианства в Юго-Западной Таврике: эпоха и вера. Киев, 2005. С. 97.

${ }^{8}$ Сорочан С. Б. Византийский Херсон ... С. 1034.

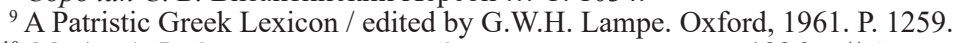

${ }^{10}$ Магда A. В. Отчет о раскопках Западного некрополя в 1996 г. // Архив Национального заповедника «Херсонес Таврический» (далее - Архив НЗХТ). Д. 3310. Л. 4, 10-11; Стржелеикий С. Ф. Краткий отчет о раскопках у Карантина за 1939 г. // Архив НЗХТ. Д. 464. Л. 7-8.

${ }^{11}$ Буйских А. В. Пространственное развитие Херсонеса Таврического в античную эпоху // Материалы по археологии, истории и этнографии Таврии. Supplementum». Вып. 5. Симферополь, 2008. C. $192-193$.

12 Латинско-русский и русско-латинский словарь / Сост. Подосинов А. В., Козлова Г. Г., Глухов А. А., Белов А. М. М., 2007. С. 501.

${ }^{13}$ Назаренко А. А. Греческо-русский словарь христианской церковной лексики (с толковыми статьями): 4500 слов и выражений. М., 2015. С. 82.

${ }^{14}$ Там же. С. 82.

15 Таврическая губерния. Раскопки в Херсонесе // Отчеты археологической комиссии за 1906 год. СПб., 1907. С. 82-83, рис. 88, 89; Туровский Е. Я., Филиппенко А. А. Отчет об археологических исследованиях участка некрополя Херсонеса у загородного храма в 2006 г. // Науковий архів Національного заповідника «Херсонес Таврійський». Д. 3856. Л. 21, 24; Туровский Е. Я., Филиппенко А. А. Хронология склепов ранних христиан некрополя Херсонеса (в свете данных раскопок 2006 г.) // Материалы по археологии и истории античного и средневекового Крыма». Вып. 1/2008. С. 45-48; Ступко М. B., Туровский Е. Я., Филиппенко А. А. О судьбах расписных склепов первых христиан Херсонеса // Sar- 
cumetprofanum. № 3. 2007. С. 189-191; Зубар В. М. Склепи з християнським розписом некрополя Херсонеса: проблеми датування // Археологія. 2009. № 2. С. 18-23; Виноградов А. Ю. Загородный крестообразный храм ... С. 227-233; Виноградов А. Ю. «Миновала уже зима языческого безумия...» ... С. 123-129; Фомин М. В. Погребальная традиция и обряд ...С. 272; IOSPEV 65, V 82, V 85; Tyровский Е. Я., Филиппенко А. А., Фомин М. В. Херсонесские склепы с раннехристианскими росписями // Дриновски сборник/Дриновський збірник. Т. V. Харків-Софія, 2012. С. 156-158; Фомин М. В., Шевцова A. А. О раннехристианских комплексах Херсонеса // Вісник ХНУ імені В.Н. Каразіна. Серія: «Історія». № 1087. Вип. 47. Харків, 2013. С. 27; Фомин М. В. О культе местночтимых святых в ранневизантийском Херсоне // Вісник ХНУ імені В.Н. Каразіна. Серія: «Історія». № 1145. Вип. 50. Харків, 2015. С. 225-227; для сравнения изображения кораблей: Thomov T. Maritimeex-votograffito from the church of Hagia Sophia, Constantinople // Byzantinoslavica. 2015. LXXIII/ 1-2. P. 57-74.

${ }^{16}$ Feissel $D$. Chroniques d'épigraphie byzantine 1987-2004. Paris, 2006. № 181, 185, 396, 410.

17 Зубарь В. М., Сорочан С. Б. У истоков христианства ... С. 97; Зубарь В. М., Хворостяныцй А. И. От язычества к христианству. Начальный этап проникновения и утверждения христианства на юге Украины (вт. пол. III - пер. пол. VI вв.). Киев, 2000. С. 82.

18 Латышев В. В. Греческие и латинские надписи, найденные в Южной России в 1895-1898 гг. // МАР. СПб., 1899. Вып. 23. С. 46-49, № 45; Сорочан С. Б. Византийский Херсон ... С. 1081; Vinogradov A. Von der antiken zur christlichen Koine ... S. 263-264, № 13; Виноградов А. Ю. «Миновала уже зима языческого безумия...» ... С. 129-132; Фомин М. В. Погребальная традиция и обряд ... С. 267; Фомин М. В. О культе местночтимых святых в ранневизантийском Херсоне // Вісник ХНУ імені В.Н. Каразіна. Серія: «Історія». № 1145. Вип. 50. Харків, 2015. С. 225-232; IOSPEV 76; Латьлшев В. В. Эпиграфические новости из Южной России // ИАК. СПб., 1908. Вып. 27. С. 28-29, № 22; Косиююико-Валюжинич К. К., Скубетов М. И. Извлечение из отчета о раскопках в Херсонесе в 1907 году // ИАК. СПб., 1911. Вып. 42, 52; Сорочан С. Б. Византийский Херсон ... С. 1080; Фомин М. В. Погребальная традиция и обряд ... С. 267; IOSPEV 62.

${ }^{19}$ Виноградов А. Ю. Загородный крестообразный храм ... С. 243; Зубарь В. М., Сорочан С. Б. У истоков христианства ... С. 74; Лькова Н. Н. Особенности трансформации символа креста на территории средневековой Таврики // «Культура народов Причерноморья». 2009. № 154. С. 84; Фомин М. В. Погребальная традиция и обряд ....С. 265, 270; IOSPEV 79.

${ }^{20}$ Сорочан С. Б. Византия. Парадигмы быта, сознания, культуры. Харьков, 2011. С. 139.

${ }^{21}$ Феодорит Киррский, блж. Церковная история / Пер. с греч. М., 1993.

22 Зубарь В. М., Хворостяный А. И. От язычества к христианству ... С. 82; Зубарь В. М., Сорочан С. Б. У истоков христианства ... С. 97.

${ }_{23}$ Лыкова Н. Н. Особенности трансформации ... С. 84.

${ }^{24}$ Матвеева Ю. Декоративные ткани в мозаиках Равенны: семантика и культурно-смысловой контекст. Киев-Харьков, 2017. С. 89-90.

${ }^{25}$ Новосадский Н. И. Несколько заметокъ о греческихъ христіанскихъ надписяхъ // Сборник Харьковского историко-филологического общества». Т. 21. Харьков, 1914. С. 296-309; Болгов Н. Н. Боспор V в.: континуитет материальной культуры «Темного столетия» // «Проблемы истории, филологии, культуры». 1998. Вып. 5. С. 45.

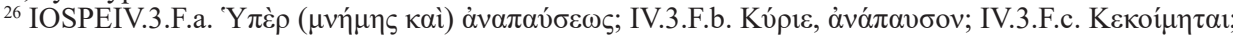

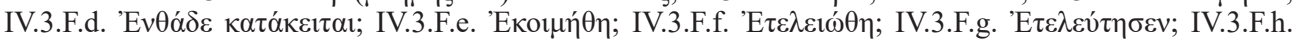

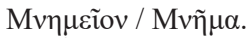

27 Латинско-русский и русско-латинский словарь ... С. 191.

${ }^{28}$ Книга Бытие, 35:20.

${ }^{29}$ Книга Царей, II.23:17; Книга Иезекииля, 39:15. 196.

${ }^{30}$ См.: Арьес Ф. Человек перед лицом смерти / Пер. с фр., ред. Оболенской С. В. М., 1992. С. $194-$

${ }^{31}$ Сорочан С. Б. Византийский Херсон ... С. 1031-1095. 